\title{
Обзор альтернативных типологий славянских языков
}

\author{
ГАБОР Л. БАЛАЖ \\ SZTE BTK Szláv Intézet, H-6722 Szeged, Egyetem u. 2. \\ E-mail: gbalazs@lit.u-szeged.hu \\ (Received: 20 September 2019; accepted: 27 November 2019)
}

Тематика типологии славянских языков была многократно затронута в разнообразных исследованиях, начиная, по-видимому, со второй половины XIX века. Первой значительной попыткой можно считать негенетическую классификацию славянских языков, сделанную Иваном Александровичем Бодуэном де Куртенэ. ${ }^{1}$

С тех пор, естественно, появились более новые работы, но нельзя сказать, что их было очень много. Поэтому цель настоящего краткого обзора обратить внимание не столько на богатство теорий, а скорее на своеобразность подходов к данной проблематике на разных уровнях изучения языка. Таким образом, целесообразно рассмотреть попытки фонологической, морфологической и синтаксической типологии славянских языков отдельно. Такое решение подтверждается и тем, что общей типологии, соблюдающей все названные уровни вместе, пока не существует.

\section{1. Фонологическая (фонетическая) типология славянских языков}

1.1. Вышеупомянутая классификация Бодуэна де Куртенэ считается первой и одновременно до сих пор чрезвычайно впечатляющей типологией славянских языков (см. Иванов 1960: 38, Н. То́тн 2004: 47). Ее популярность объясняется отчасти тем, что, пользуясь всего двумя фонологическими критериями, можно определить пять типов славянских языков.

Выбранные И. Бодуэном де Куртенэ критерии следующие: а) характер ударения (подвижное или постоянное) и б) противоположность (оппозиция) долгих и кратких гласных. При применении этих критериев получаются следующие типы:

\footnotetext{
${ }^{1}$ Подробная программа лекций И. А. Бодуэна де Куртенэ в 1877-1878 учебном году. Известия и ученые записки имп. Казанского университета. Разд. «Известия». Казань, 1879. 144 145.
} 


\begin{tabular}{|l|c|c|}
\hline & $\begin{array}{c}\text { оппозиция долгих и } \\
\text { кратких гласных }\end{array}$ & $\begin{array}{c}\text { подвижное } \\
\text { ударение }\end{array}$ \\
\hline (1) сербскохорватские наречия & + & + \\
\hline (2) словенские наречия & $(+)^{2}$ & + \\
\hline $\begin{array}{l}\text { (3) болгарские и русские } \\
\text { наречия и говоры }\end{array}$ & - & - \\
\hline $\begin{array}{l}\text { (4) чешские и словацкие наречия } \\
\text { (5) польские, лужицкие и } \\
\text { кашубские говоры }\end{array}$ & + & - \\
\hline
\end{tabular}

1.2. В связи со своей типологической классификацией, которая несомненно сильно напоминает только что представленную систему Бодуэна де Куртенэ, Роман Якобсон указывает на то, что вследствие падения редуцированных гласных значительно изменились просодические условия в славянских языках (JАKOBSON 1955: 15-17). Он устанавливает следующие типы и подтипы:

(1А) сербскохорватский и словенский: наличие музыкального ударения и оппозиции долгих и кратких гласных;

(1Б) севернокашубский: ${ }^{3}$ под ударением оппозиция долгих и кратких гласных отсутствует;

(2) чешский и словацкий: фиксированное ударение, оппозиция долгих и кратких гласных;

(3) польский, восточнословацкий, русинский; лужицкие языки, южнокашубский; (западно)македонский: фиксированное ударение, отсутствует оппозиция долгих и кратких гласных;

(4) восточнославянский, болгарский, восточномакедонский: подвижное ударение, отсутствие количественных противопоставлений.

Якобсон добавляет несколько дальнейших критериев к своей классификации, из которых наиболее интересным является установление определенных соотношений между просодическими критериями и фонемным составом отдельных языков:

- для типов (1) и (2) характерно большее количество гласных фонем, в то время как для типов (3) и (4) - преобладание согласных; и (2);

- плавные приобретают слогообразующую функцию лишь в типах (1A)

- тип (4) склонен к уменьшению количества гласных фонем в неударяемых слогах (в севернорусских диалектах их четыре, в южнорусских и белорусских - три: [u], [a], [i]);

\footnotetext{
2 Только в ударяемых слогах.

${ }^{3}$ Раньше самостоятельный кашубский язык в последнее время часто считается диалектом польского языка.
} 
- тип (1А) уменьшает фонемный состав задненебных согласных (утрачивается в первую очередь $x$, в некоторых словенских диалектах даже $\kappa$ и г);

- двойные согласные допускаются только в языках типов (3) и (4);

- противопоставление твердых и мягких согласных фонем постепенно устраняется в типах (1Б) и (2), зато сохраняется или даже усиливается в (4) и в большинстве языков (3);

- за исключением словенского и кашубского языков, в языках, не развивших или утративших палатализацию как различительный признак, приобрели четвертый, палатальный ряд смычных согласных кроме губных, зубных и задненебных (особенно в сербскохорватском, чешском и словацком).

1.3. Эдвард Станкевич делит современные славянские языки на два основных типа на основе их просодических свойств, подобно уже упомянутым выше языковедам (STANKIEWICZ 1958: 13-14). Его классификация выглядит таким образом:

Тип А - языки, в которых просодические свойства не имеют различительной функции; в этих языках ударение является фиксированным в одной позиции (на одном слоге): польский, верхнелужуицкий и нижнелужуицкий, западномакедонский, южнокашубский, восточнословацкий, ляшский и лемковский (Ukrainian Lemki). ${ }^{4}$

Тип Б - языки, в которых просодические свойства имеют различительную функцию; внутри этих языков Станкевич определяет четыре подтипа:

1) системы с дистинктивным ударением: восточнославянские языки, болгарский, севернокашубский, призренско-тимокский диалект ${ }^{5}$ и восточномакедонские диалекты;

2) системы с дистинктивными количественными различиями (с оппозицией долгих и кратких гласных): чешский и словацкий (кроме диалектов, причисленных к типу А выше);

3) системы с дистинктивным ударением и с дистинктивными количественными различиями: много периферийных сербохорватских и словенских диалектов (особенно приморские и штирийские);

4) системы с дистинктивным музыкальным ударением; наличие тона предполагает наличие количественных различий: большинство сербскохорватских и словенских диалектов; здесь выделяются два подтипа:

4a) системы, в которых позиция нисходящего тона предсказуема; эти системы используют лишь два просодических свойства (количество и тон);

4b) системы, в которых позиция нисходящего тона не предсказуема; эти системы используют три просодических свойства (количество, различение ударяемых и неударяемых гласных и тон).

Подобно Якобсону, Станкевич тоже указывает на соотношение между просодическими признаками и фонемным составом славянских языков. При этом он устанавливает следующие общие фонологические типы:

\footnotetext{
${ }^{4}$ Cр. у Якобсона: русинский (Rusnak).

${ }^{5}$ По-другому, торлакское наречие.
} 
I) Системы с дистинктивной палатализацией согласных - они допускают лишь два просодических типа: а) дистинктивное ударение и, в некоторых случаях, б) дистинктивное ударение и количество; просодические признаки могут полностью отсутствовать; часто наблюдается преобладание согласных.

II) Системы без дистинктивной палатализации согласных - они могут характеризоваться любым просодическим типом: а) тоном (музыкальным ударением), б) количеством (т. е. количественным различением долгих и кратких гласных) и, в меньшей степени, в) ударением и количеством, или г) ударением; при наличии двух или больше просодических признаков количество гласных фонем может совпадать с количеством согласных, или превышать его.

III) Системы без дистинктивной палатализации согласных и без просодических признаков - в них количество фонем меньше, чем в типах I и II.

1.4. Касаясь типологической проблематики, обязательно следует отметить еще одного слависта, несмотря на то, что он известен в языкознании скорее иными достижениями. Дело в том, что Юрий Шевелев в своей основополагающей работе, посвященной фонологической истории праславянского языка, подробно занимается и вопросами классификации славянских языков (SHEVELOV 1964: 574-578, 595-601). С чисто просодической точки зрения он дает такую классификацию:

а) языки с оппозицией по тону, долготе/краткости гласных и ударению, хотя с определенными позиционными ограничениями: сербскохорватский;

б) языки с оппозицией по ударению и долготе/краткости гласных: словенский (долгота только под ударением);

в) языки без оппозиции по тону и ударению, но с оппозицией по количеству (т. е. по долготе/краткости гласных): словацкий, чешский;

г) языки без каких-либо просодических оппозиций: польский, лужицкие языки, македонский;

д) языки без оппозиции по тону и количеству, но с оппозицией по ударению: русский, белорусский, украинский, болгарский.

Эту просодическую классификацию далее в своей книге Шевелев оттачивает тем, что указывает на соотношение просодических признаков с набором гласных звуков в отдельных славянских языках. ${ }^{6}$ Таким образом, он устанавливает три главных типа славянских фонологических систем гласных:

1) ядро с пятью гласными (которое может увеличиться дальнейшими членами до шести или семи); нет фонологически значимых просодических признаков: польский, лужицкие языки, македонский;

2) ядро с пятью гласными (которое может увеличиться дальнейшими членами до шести); фонологически значимые просодические признаки: а) (подтип с ударением, но без количества) русский, белорусский, украинский (вне ударения); б) (подтип с количеством) словацкий (с долготой), чешский, словенский (с долготой), сербскохорватский;

\footnotetext{
${ }^{6}$ Фонемный состав согласных Шевелев рассматривает отдельно, независимо от данных типологических наблюдений. 
3) ядро с шестью гласными; два просодически обусловленных подтипа: украинский (под ударением), словацкий (с краткостью), словенский (с краткостью), болгарский.

1.5. Сходство представленных выше классификаций славянских языков (и диалектов), несомненно, поразительно. Так как Бодуэн де Куртенэ не занимался установлением соотношений между просодическими типами и фонемным составом (ср. ИвАнов 1960: 39-40), типологические системы четырех языковедов можно сопоставить путем выявления просодических признаков (см. выше) и соответственных им типов в следующей таблице:

\begin{tabular}{|c|c|c|c|c|}
\hline $\begin{array}{c}\text { Типы } \\
\text { Бодуэна де } \\
\text { Куртенэ }\end{array}$ & $\begin{array}{c}\text { Типы } \\
\text { Якобсона }\end{array}$ & $\begin{array}{c}\text { Типы } \\
\text { Станкевича }\end{array}$ & $\begin{array}{c}\text { Типы } \\
\text { Шевелева }\end{array}$ & Языки и наречия \\
\hline 1 & $1 \mathrm{~A}$ & Б3, Б4 & а & сербский, хорватский \\
\hline 2 & $1 \mathrm{~A}$ & Б3, Б4 & б & словенский \\
\hline 3 & 4 & Б1 & д & $\begin{array}{c}\text { восточнославянские } \\
\text { языки, болгарский }\end{array}$ \\
\hline 4 & 2 & Б2 & в & чешский, словацкий \\
\hline 5 & 3 & А & г & $\begin{array}{c}\text { польский, лужицкие } \\
\text { языки, македонский }\end{array}$ \\
\hline
\end{tabular}

\section{2. Морфологическая типология славянских языков}

В отличие от более успешной фонологической классификации, впервые разработанной Бодуэном де Куртенэ, до сих пор нет надежной морфологической классификации славянских языков. Существуют, однако, отдельные попытки, которые, вместе с интересными выявлениями о соотношении такой классификации с лингвогеографическими данными, указывают и на недостатки морфолого-типологических подходов.

2.1. Одна из первых попыток классификации славянских языков по морфологическим критериям принадлежит ученику Бодуэна де Куртенэ, одному из основателей казанской лингвистической школы - Василию Алексеевичу Богородицкому. Он рассмотрел морфемы окончания первого лица единственного числа настоящего времени изъявительного наклонения в отдельных славянских литературных языках и пришел к выводу, что эти языки могут быть распределены в этом отношении на две группы - восточную и западную. В восточнославянских языках почти исключительно употребляется окончание $-y$ в то время как окончание $-м$ сохранилось в более скудных остатках, чем в старославянском (дам, ем). Остальные славянские языки в большей или меньшей мере распространили это последнее окончание, которое, впрочем, является флексией старого атематического спряжения. Богородицкий 
располагает данные языки в порядке возрастающего употребления окончания -м: в болгарском языке окончание -ам встречается у некоторых глаголов, соответствующих русским глаголам на -aю, в которых ударение падает на предпоследний слог; у остальных таких глаголов употребляется окончание -я [jъ]. В польском языке у этих глаголов встречается только -am, так как ударение всегда падает на слог, предшествующий окончанию. В чешском действие аналогии оказывается еще сильнее, так как здесь возможны лишь окончания -ám и -ím. В сербскохорватском языке наблюдается еще большее распространение окончания атематического спряжения, ведь флексия -м (-aм, -ем, -uм) является общим, всего с двумя исключениями могу и хоћy. ${ }^{7}$ В словенском уже все глаголы получают окончание $-m$. Богородицкий указывает на следующее соотношение между употреблением отдельных окончаний и географическому распределению данных языков: «...pусскій языкъ съ одной стороны и западный отдъль южных языковъ (т. е. сербскій съ словинскимъ) с другой составляють противоположность; болгарскій и польскій, какъ непосредственные сосьди русскаго языка, представляютъ соотвђтственно слабое распространеніе окончанія -m (они представляютъ ту стадію, которую проходиль сербскій около XIII в.); чешскій языкъ, занимающій географическое положеніе между польским языкомъ и западными задунайскими, вмђсть съ тЂмъ занимаетъ посредствующее между ними положеніе и по распространенности окончанія -m въ 1 ед. (напоминая состояніе сербскаго языка передъ XV в.)» (Богородицкий 1917: 190-191; ср. Н. То́тн 2004: 49).

\section{2. Распространение рефлексов праславянского окончания -оvъ в отдельных славянских языках ${ }^{8}$}

Окончание -ovъ, как известно, встречается не во всех славянских языках. Так как в современном болгарском и македонском вообще отсутствует именное склонение, естественно, что вместе с остальными флексиями косвенных падежей исчезли и маркеры род. п. обоих чисел. ${ }^{9}$ В сербском и хорватском языках склонение уцелело, но ни в одной именной парадигме не встречается рефлекс флексии -оvъ: в качестве окончания род. п. мн. ч. выступают только морфемы $-\bar{a}^{10},-\bar{\imath}$ и $-i j \bar{u}$. Несомненно, однако, что более ранние письменные памятники и этих четырех языков тоже свидетельствуют о распространении окончания -ovъ.

Что касается судьбы данной флексии в остальных славянских литературных языках, она подвергалась тщательному анализу (см. особенно BREU 1988 и JANDA 1996), поэтому в последующем я буду ссылаться на эти две работы.

${ }^{7}$ Богородицкий приводит еще вељу и виђу, которые уже спрягаются как велим, видим.

${ }^{8}$ Об истории и подробном анализе данного окончания см. БАЛАж 2012.

${ }^{9}$ Своеобразными остатками окончания -оvъ можно считать местоименные формы типа еговъ, неговъ, тоговъ, сеговъ, оноговъ (ДуридАНОв 1983), а в современном болгарском негов, негова, негово, негови.

${ }^{10}$ О возникновении окончания - $\bar{a}$ см., например, JoHNSON 1972. 
Единственный современный южнославянский язык, в котором употребляется окончание -ovъ - это словенский. В этом языке все существительные мужского рода в род. п. мн. ч. получают окончание -ov/-ev (последнее употребляется после палатальных согласных), за исключением шести слов (konj, las, mož, otrok, voz, zob ${ }^{11}$ ). Следует добавить, что большинство односложных существительных м. p. в двойственном и множественном числах перед флексиями имеет слоговой аугмент -ov-, восходящий тоже к старым *-й- основам (как и в сербском и хорватском языках) (cp. DE BRAY 1980a: 344). За пределами существительных м. р. род. П. мн. ч. -ov/-ev не наблюдается.

В русском языке ситуация похожая, так как окончание -ов/-ев присоединяется главным образом к существительным мужского рода, хотя здесь уже появляются определенные исключения. Кроме того, после палатальных или палатализованных согласных выступает алломорф -ей из -ц̌- основ. ${ }^{12}$ Заслуживает внимания спорадическое распространение окончания -ов в ср. и ж. р.

В украинском языке флексия -iв/-їв (<-ovъ) является практически универсальным для существительных м. р., независимо от парадигмы (ср. суддів - род. п. мн. ч. от суддя). Исключение составляют лишь следующие случаи: 1) существительные м. p. с суффиксом -ин, которые получают нулевое окончание в род. п. мн. ч., 2) слова, которые часто выступают в количественных оборотах, например, день, раз, рік, чоловік (с альтернативными формами день / днів и др.), 3) существительные кінь, гість, гріш с формами род. п. мн. ч. коней, гостей, грошей. Со временем окончание -ів/-їв появилось в женском роде (и в твердых, и в мягких парадигмах) и в среднем роде (только с основами на мягкий согласный). У существительных женского рода, однако, оно является альтернативной флексией, например, бабів/баб, губів/губ, хатів/ $x a m$ (но только матерів; от форм им. п. ед. ч. баба, губа, хата, мати). В среднем роде -ів/-їв употребляется небольшим числом существительных, например, море-морів, поле - полів, почуття-почуттів, відкриття-відкриттів, прислів'я - прислів'їв, подвір'я - подвір'їв (ср. JANDA 1996: 109-110, DE BRAY 1980c: $120-128$ ).

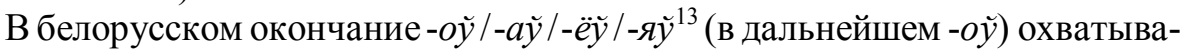
ет довольно широкий круг слов, так как оно встречается во всех флективных классах. Кроме м. р., где оно является почти единственным маркером род. п. мн. ч. (за исключением существительных с суффиксами -анін, -янін, -ін, -ын и слов, часто выступающих в количественных оборотах, например, дзень, раз, чалавек), данная флексия стала исключительной для мягких основ среднего рода и твердых основ с группой согласных (не допускающих беглых гласных) в конце основы, и альтернативной для всех остальных, с незначительными исключениями (например, слова - слой). В склонении существительных бывших $(j) \bar{a}$ - и $\breve{l}$ - основ флексия -ог̆ типично появляется как альтернатива

\footnotetext{
${ }^{11}$ В род. п. мн. ч. voz и zob имеют дублетные формы voz/vozov и zob/zobov.

${ }^{12}$ Окончание -ей также выражает максимально иконичное отношение, как и -ов, в отличие от исходного -Ø.

${ }^{13}$ Выбор алломорфа зависит от места ударения и характера предыдущего согласного.
} 
(ср. бомба - бомб/бомбай, зямля - зямель/земляў, дробязь - дробязей/дробязяў), в некоторых случаях она является единственно возможной, например, роля - роляў, рэч - рэчай, бітва - бітвац̆, госия - госияй. В последних двух примерах, безусловно, важную роль играет наличие группы согласных в конце основы (JANDA 1996: 110, МАYO 1993: 903-904).

Для польского языка характерно употребление окончания -ów/-iów в парадигмах существительных м. р. с твердой основой (включая и те, которые в им. п. ед. ч. оканчиваются на $-a$ ), и большинства существительных м. p. с мягкой основой. В остальной части последней группы у одушевленных существительных приоритетом пользуется, как правило, окончание -ów/-iów, а у неодушевленных $--y /-i{ }^{14}$ Одушевленные существительные м. p. из бывшей $-(j) \bar{a}$ основы в ед. ч. получают окончания ж. р., так как во мн. ч. они имеют флексии м. p. Нулевое окончание встречается лишь в следующих случаях: 1) с одушевленными существительными на -anin, 2) в названиях местностей pluralia tantum (типа Czechy), 3) со словом procent в сочетании с числительными, 4) с существительными przyjaciel и nieprzyjaciel и 5) в устойчивых словосочетаниях типа dotychczas. Хотя флексия -ów/-iów употребляется в мужском роде, она появляется и в среднем (с заимствованиями на -um: gimnazjum-gimnazjów) (JANDA 1996: 107-108, DE BRAY 1980b: 267-281).

В чешском языке окончание - $u$ (< ovъ) стало общим для существительных м. p. всех парадигм (ср. hrdina-hrdinů), за исключением следующих случаев, в которых употребляется нулевое окончание: 1) название местностей pluralia tantum типа Čechy; 2) существительные, часто встречающиеся в количественных оборотах (например, tisic - tisic, penize - penéz); 3) существительные pritel, nepritel; 4) существительные с альтернативными флексиями в род. П. мн. ч. (например, den - dní/dnů, kůn̆ - koní/koňì) (JANDA 1996: 108109, SHORT 1993: 467-468).

В словацком положение подобное чешскому, даже исключения большей частью совпадают. Существительные м. p. на - $a$ также выступают с окончаниями ŏ-основ, например, sluha - sluhov (JANDA 1996: 109, DE BRAY 1980b: 161-162).

Лужицкие языки представляют особый тип с точки зрения употребления род. п. мн. ч. -ow. И в верхнелужицком, и в нижнелужицком данное окончание является общим для всех существительных, независимо от их рода и флективного класса. ${ }^{15}$ Исключений, когда окончание род. п. мн. ч. заменяется флексией - $i$ или -Ø, очень мало (например, kokoš - kokoši, njedźela - njedźel, husa - husow/hus, lěto - lět, jejo - jeji). Таким образом, -оw в этих языках достигло максимальной дистрибуции в системе склонения существительных (cp. DE BRAY 1980b: 382, 392).

${ }^{14}$ О более подробном распределении флексий род. п. мн. ч. у производных существительных см. JANDA 1996: 108.

${ }^{15}$ Окончание -ow стало единственным маркером и для род. п. дв. ч. (в нижнелужицком в форме -оwu).

Studia Slavica Hung. 64, 2019 
Малочисленные письменные памятники полабского языка не содержат примеры на распространение окончания - $\ddot{u} v /-e v(<-o v ъ)$ за пределами существительных м. р. с основой на -(j)ら (POLAŃSKI 1993: 808-810).

На основе данных современных славянских литературных языков Брой делает следующее обобщение по поводу окончания род. п. мн. ч.: неразличение флективных типов сильнее всего осуществилось в нижнелужицком и верхнелужицком языках, а за ними следуют сербский, хорватский и белорусский. В лужицких языках произошел следующий морфологический процесс: $\ll 1$. /o-, jo- $\rightarrow$ u- (Maskulina), 2./n. $\rightarrow$ m., 3. /a-, ja- $\rightarrow$ o-, jo- (Maskulina), 4. /f. $\rightarrow$ m., 5. i- $\rightarrow$ ja-». Все другие славянские языки с небольшими отклонениями остались в промежуточных стадиях этого процесса (при особом положении сербского и хорватского).

В данном отношении самыми прогрессивными оказались существительные м. р., а в ср. и ж. роде изменения осуществились реже и медленнее (если вообще были). Первичной мотивацией для такого явления по Брою послужил тот факт, что в склонении -(j)б основ род. п. мн. ч. и им. п. ед. ч. совпадали в -Ø, в то время как в остальных парадигмах такого синкретизма не было (BREU 1988: 253).

К несколько иным выводам приходит Янда, которая посвятила целую (и ценную) монографию распространению прежних непродуктивных морфологических окончаний и категорий. Причиной распространения окончания - ovъ - кроме упомянутого и Броем синкретизма - она считает и иконичность данной флексии (см. выше). Рефлексы -ovъ она изображает с помощью следующей схемы: ${ }^{16}$

\begin{tabular}{|c|c|c|}
\hline & & Русский \\
\hline & Белорусский & твердые основы м. p. \\
\hline Польский & Усе склонения & \\
\hline $\begin{array}{c}\text { твердые основы м. p.; } \\
\text { одушевленные } a \text { - } \\
\text { основы м. р.; основы } \\
\text { ср. р. на -ит }\end{array}$ & $\begin{array}{c}\text { основы м. } \text {.; одушев- } \\
\text { ленные } a \text {-основы; } \\
\text { мягкие основы ср. p. }\end{array}$ & \\
\hline Чешский, словацкий & & \\
\hline $\begin{array}{c}\text { основы м. р.; одушев- } \\
\text { ленные } a \text {-основы м. p. }\end{array}$ & & \\
\hline Словенский & & \\
\hline основы м. р. & & \\
\hline
\end{tabular}

${ }^{16}$ Сербским, хорватским и лужицкими языками Янда в своей работе не занимается. 
По этой схеме Янда устанавливает, что существует ясная линия возрастающего применения -ovъ с юго-запада на северо-восток, кульминируя в почти универсальном распространении данного окончания в белорусском, ${ }^{17}$ продолжая с крутым спадом по пути к русскому языку (JANDA 1996: 113-114). Нетрудно заметить, что установленная Яндой «линия» практически совпадает с представленным выше распространением окончания - $m$, намеченным Богородицким.

Какими бы наглядными и элегантными ни представлялись приведенные схемы Янды и Броя, они неизбежно немного упрощают факты, так как они ограничиваются анализом славянских литературных языков. Вовлечением морфологических данных отдельных диалектов в исследование, нарисованную выше картину можно уточнить и дополнить. На основе данных диалектов польского и русского языков однозначно можно установить, что на основе своих говоров они принадлежат тому же типу, как и белорусский, т. е. рефлексы окончания -ovb - хоть бы факультативно - употребляются во всех флективных классах (во всех типах склонения) существительных. Это относится и к детской речи, и к определенным социальным диалектам ${ }^{18}$ (БАЛАж 2012: 38-41).

\section{3. Распространение окончаний творительного падежа множественного числа в отдельных славянских языках ${ }^{19}$}

Как известно, «антииконические» формы в грамматической системе в большинстве случаев устраняются, причем на их месте появляются новые, иконические маркеры, которые повышают морфологическую естественность (т. е. менее высокую степень маркированности) данной грамматической системы. Так обстоит дело и с праславянским по происхождению окончанием тв. п. мн. ч. $-y /-i$. В современных славянских языках обыкновенно находим результаты такого процесса, поскольку рассмотренная грамматическая категория выражается через рефлексы окончания -mi (-ami, -emi, -mi). Эти рефлексы употребляются в русском, украинском, белорусском, словацком, польском, в верхнелужуицком и нижнелужицком языках. В них однофонемного окончания вообще не существует. В сербском и хорватском встречаются - ата и -іта, которые являются флексиями - вместе с творительным - и дательного, и местного падежей. Эти особые формы, отражающие опрощение морфологической системы в еще большей степени, происходят из двойственного числа. Таким образом, можно установить, что относительно морфемы тв. П. мн. ч. в девяти из тринадцати современных литературных славянских

${ }^{17}$ Если берем в расчет и лужицкие языки, они несомненно займут высшую ступень распространения -оvъ (как у Броя).

${ }^{18} \mathrm{Cp}$., например, следующие русские примеры из интернета: вся правда в выборе судьев (вм. судей), учебничек для взросльх дядев (вм. дядей) и тётев (вм. тётей), наивность дедуиков (вм. дедушек) - штука тонкая и т. д.

${ }^{19}$ Подробный анализ см. БАЛАЖ 2016. 
языков однозначно выражается конструкционная иконичность (диаграмматичность). Так как в болгарском и македонском уже нет падежных окончаний в именной системе, данное соотношение на самом деле - 9 из 11.

Только в чешском и словенском отсутствует стандартизация окончания

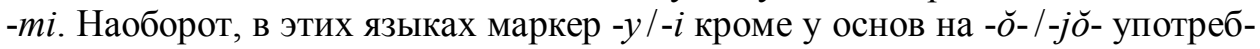
ляется и в консонантных парадигмах, ср. чешский kameny, kuřaty; словенский jagnjeti, bremeni, očesi и др. Следовательно, этот маркер, вместо того, чтобы исчезнуть, становится еще более продуктивным. В обоих языках существует синкретизм И $=\mathrm{T}$, а в чешском есть и $\mathrm{B}=\mathrm{T} .{ }^{20} \mathrm{~B}$ словенском в среднем роде маркер - $i$ совпадает с флексией именительно-винительного падежа двойственного числа, точно как в праславянском и в старославянском. Естественно, здесь об иконическом кодировании и речи быть не может, так как отношение между флексиями единственного и множественного числа остается антииконическим. Чем объясняется такое сопротивление распространению более иконических маркеров, ставших исключительными в остальных славянских языках?

Старославянский как первый нормализованный литературный язык славян по известным причинам пользовался огромным престижем и оказывал значительное влияние на развитие отдельных славянских литературных языков. Приведенные выше морфологические факты свидетельствуют о том, что старославянская традиция однозначно и очень наглядно отражается в грамматической системе чешского и словенского языков.

Данное положение, по всей вероятности, не случайно напоминает судьбу маркера род. п. мн. ч. -ovъ, заместившего исходную праславянскую флексию -ъ. Как было отмечено выше (см. 3.2.), Л. Янда в своей монографии, посвященной (в древности) непродуктивным окончаниям, устанавливает, что существует ясная линия продуктивности маркера -оvъ с юго-запада на северовосток (см. 3.2.). По ее диаграмме видно, что языки, наиболее сильно сопротивляющиеся распространению новой морфемы -ovъ, это именно словенский и чешский. Таким образом, тезис о своеобразной морфологической консервативности этих языков получает значительное подкрепление. Не следует забывать, однако, что сказанное характеризует в первую очередь литературные языки, являющиеся строго кодифицированными и нормализованными. В то же время разговорная речь и ее диалекты в значительной мере делают возможным распространение «новых» окончаний, проявляя при этом стремление к установлению или восстановлению языковой естественности.

\section{3. Синтаксическая типология славянских языков}

3.1. Существует интересная типологическая классификация европейских (в том числе и славянских) языков, которая основывается скорее на синтаксических параметрах, нежели на морфологических. Имеется в виду попытка

${ }^{20}$ И - окончание именительного падежа, В - ок. винительного п., Т - ок. творительного п. 
Хаспельмата собрать доказательства о существовании лингвистического ареала, включающего в себя романские, германские, балто-славянские, балканские и, более маргинально, западные угро-финские языки. Следуя термину Б. Уорфа, этот ареал часто называют Языки среднеевропейского стандарта (CEC) (Standard Average European) (НаSpelmath 2001: 1492). Хаспельмат пользуется двенадцатью параметрами, выбранными на основе следующих принципов:

I. в подавляющем большинстве «ядерных» европейских языков данный признак существует;

II. в географически смежных языках (в кельтских, тюркских, восточных уральских, абхазо-адыгских и нахско-дагестанских) его нет;

III. в восточных индоевропейских языках (в армянском, иранских и индийских) его нет;

IV. данный признак отсутствует в большинстве языков мира.

На такой основе Хаспельмат выделил следующие параметры:

1. наличие определенного и неопределенного артиклей;

2. относительные предложения с относительными местоимениями;

3. образование перфекта с глаголом «иметь»;

4. [выражение «экспериенсера» при помощи номинатива (чувства, восприятия и т. д.); $]^{21}$

5. пассивная конструкция с пассивным причастием;

6. [предпочтение производных декаузативных глаголов перед каузативами (типа иметь / иметься, встречать/встречаться и пр.;]

7. выражение внешнего обладателя при помощи дательного падежа;

8. отрицательные местоимения при отсутствии глагольного отрицания;

9. [использование частиц в сравнительных конструкциях];

10. эквативные конструкции на основе адвербиальных относительных предложений;

11. обязательное употребление субъектных местоимений;

12. различение форм интенсификаторов и рефлексивов (cp. нем. selbst и sich) (Haspelmath 2001: 1493-1501).

В результате применения приведенных параметров к языкам Европы получается своеобразная иерархия. В зависимости от того, сколько из девяти признаков, выбранных в конечном итоге, встречаются в отдельных языках, Хаспельмат устанавливает, что ядром языков СЕС являются французский и немецкий (с 9 параметрами из 12), близко к ним стоят голландский, итальянский, испанский, португальский и албанский (по 8 параметров), а потом английский, румынский и греческий (по 7 параметров), шведский, норвежский, исландский и чешский (по 6 параметров), литовский, латышский, венгерский, русский, украинский, польский, болгарский, сербский, хорватский и словенский (по 5 параметров). Остальные языки Европы, как например,

\footnotetext{
${ }^{21}$ Параметры в квадратных скобках не были включены Хаспельматом в конечный счет из-за отсутствия для них достаточной информации.
} 
финно-угорские (за исключением венгерского), турецкий, армянский, кавказские и кельтские языки не входят в языковой союз CEC (см. HASPELMATH 2001: 1505).

И сам Хаспельмат признает, что выбранные параметры не являются репрезентативными для европейских языков, так как они служат именно для иллюстрации и подтверждения гипотезы о языках СЕС. Кроме того, определение некоторых признаков для отдельных языков оспоримы, что может ослабить правдоподобность результатов. Также проблематична высокая степень субъективности и упрощенность анализа данных (ср. БАЛАж 2014: 17).

3.2. По поводу выше изложенной концепции Хаспельмата о языках СЕС важные уточнения добавил Томмола, по мнению которого признаки, предложенные как общие для европейских языков, не являются безусловно оптимальными для сопоставительных исследований (ТOMMOLA 2011). ${ }^{22}$ В своей статье он рассматривает все 12 параметров и их подтипы путем многочисленных примеров, обращая особое внимание на угро-финские и славянские языки, и устанавливает, что критерии, принятые для определения типичных европейских признаков, оказались до известной степени противоречивыми, а применение этих признаков - иногда слишком прямым. Другими словами, игнорируется значительное варьирование в употреблении альтернативных средств для выражения тех или иных значений, например, в славянских языках (TOMMOLA 2011: 365).

К своему анализу Томмола прилагает таблицу с математически исчисленными статистическими корреляциями (величинами между -1 и +1 ) $^{23}$ между конкретными языками (см. ниже). ${ }^{24}$ На основе скалькулированных корреляций он приходит к значительным выводам, из которых я хочу здесь подчеркнуть лишь два: 1) среднее расстояние между родственными языками значительно меньше, чем их расстояние от других (неродственных) языков; 2) болгарский язык стоит далеко не только от угро-финских и германских языков, но и от русского, так как корреляция между болгарским и русским $(0,41)$ чуть больше корреляции между, например, русским и эстонским $(0,35)$. С другой стороны, болгарский язык проявляет высокую корреляцию относительно других славянских языков, особенно македонского $(0,87)$, сербского и хорватского, словацкого, польского, белорусского $(0,64)$ и чешского $(0,56){ }^{25}$

Следует добавить, что незначительное число типологических отличий в морфологии и синтаксисе славянских языков объясняется не столько недостатками выше упомянутых средств и способов типологических исследований, а скорее тем фактом, что языки славянства по сей день остались в структурном отношении близкими друг к другу, поэтому генетическая связь между ними сильнее, чем различия в той или иной классификации.

\footnotetext{
22 Рецензию на статью Томмолы и книгу, содержащую ее, см. ДьЁРФи 2013.

23 Чем больше это число, тем ближе друг к другу данные два языка.

${ }^{24} \mathrm{~B}$ приведенной здесь таблице отмечены только данные славянских языков.

${ }^{25}$ К сожалению, остальные славянские языки Томмола не включил в свой анализ.
} 


\begin{tabular}{|c|c|c|c|c|c|c|c|c|}
\hline Язык & $\begin{array}{c}\text { бело- } \\
\text { рус. }\end{array}$ & $\begin{array}{c}\text { рус- } \\
\text { ский }\end{array}$ & $\begin{array}{c}\text { чеш- } \\
\text { ский }\end{array}$ & $\begin{array}{c}\text { поль- } \\
\text { ский }\end{array}$ & $\begin{array}{c}\text { словац- } \\
\text { кий }\end{array}$ & $\begin{array}{c}\text { болгар- } \\
\text { ский }\end{array}$ & $\begin{array}{c}\text { маке- } \\
\text { донск. }\end{array}$ & $\begin{array}{c}\text { серб.- } \\
\text { хорв. }\end{array}$ \\
\hline белор. & & 0,82 & 0,68 & 1 & 0,74 & 0,64 & 0,51 & 0,74 \\
\hline русск. & & & 0,62 & 0,82 & 0,56 & 0,41 & 0,28 & 0,69 \\
\hline чешск. & & & & 0,68 & 0,94 & 0,56 & 0,56 & 0,94 \\
\hline польск. & & & & & 0,74 & 0,64 & 0,51 & 0,74 \\
\hline словац. & & & & & 0,64 & 0,64 & 0,87 \\
\hline болг. & & & & & & & 0,87 & 0,64 \\
\hline макед. & & & & & & & & 0,64 \\
\hline
\end{tabular}

\section{Заключение}

На основе вышеприведенных фактов можно привести следующие итоги по поводу типологии отдельных языковых уровней славянских языков.

Наиболее единообразной является фонологическая типология, так как во всех представленных моделях ключевую роль играют два просодических признака - оппозиция долгих и кратких гласных, с одной стороны, и характер ударения, с другой. Таким образом фонологическая классификация, впервые разработанная Бодуэном де Куртенэ, оказалась весьма надежной до сих пор. Соревнующихся иных теорий в этой области пока не видно.

Что же касается морфологической типологии, тут нельзя определить подобных фонологическим моделям признаков или критериев, которыми можно было пользоваться при определении каких-либо морфологических типов. Славянские языки (даже болгарский и македонский, лишающиеся именного склонения, ср. БАЛАЖ 2014) остались фузионными (флективными) языками, внутри которых нелегко обособить дальнейшие подтипы. Единственным способом категоризации кажется выявление и сопоставление единичных грамматических признаков отдельных языков, как это было представлено в 2.1., 2.2. и 2.3.

Синтаксическая типология славянских языков пока является очень молодой областью типологических исследований, поэтому здесь подвести какихлибо общих итогов (кроме выше уже упомянутых) нельзя. Модель, предложенная для языков Европы Хаспельматом, кажется многообещающей, но нуждается в дальнейшей выработке подробностей и специфических способов ее применения относительно именно славянских языков.

Наконец, нельзя не заметить, что типологические закономерности, отмеченные как при морфологических, так и синтаксических наблюдений в разделах 2 и 3 , до известной степени совпадают с фактами ареальной классификации славянских языков, как это было отмечено Богородицким, Янда, Томмола и другими исследователями. 


\section{Литература}

БАЛАж 2012 = БАЛАж Г. Л. Распространение окончания -овъ в свете данных славянских диалектов. Slavica 41. Debrecen, 2012. 31-43.

БАЛАж 2014 = БАЛАж Г. Л. Натурално-морфологична интерпретация на структурни промени в историята на българския език. В кн.: Трети международен конгрес по българистика, 23-26 май 2013 г. София: Университетско издателство «Св. Климент Охридски», 2014. 7-19.

БАЛАж 2016 = БАЛАж Г. Л. Към историята на флексиите за творителен падеж множествено число в славянските езици. В кн.: Българистични четения. Международна научна конференция. Сегед, 11-12 юни 2015 г. Szeged: JATE Press 2016. 7-17.

БогОРодицкий 1917 = БогоРодицкий В. А. Краткій очеркъ сравнительной грамматики аріо-европейскихъ языковъ. Казань: Типо-литографія Университета, 1917.

ДуридАнов 1983 = ДуридАнов И. Пътят на българския език от синтетизъм към аналитизъм. В кн.: Христоматия по история българския език. София: Наука и изкуство, 1983. 259-272.

ДьЁРФИ 2013 = ДьЁРФИ Б. Обзор новейших исследований по формальному описанию грамматических явлений славянских языков. Slavica 42. Debrecen, 2013. 211-221.

ИвАНОВ 1960 = ИвАнов В. В. Бодуэн де Куртенэ и типология славянских языков. В кн.: БЕРНШТЕЙН С. Б. (ред.) И. А. Бодуэн де Куртенэ (к 30-летию со дня смерти). Москва: Издательство АН СССР, 1960. 37-43.

BREU 1988 = BREU W. Die Entwicklungstypen der Flexionsformen des Genitivs im Plural der slavischen Sprachen. In: Studia Indogermanica et Slavica. Festgabe für Werner Thomas zum 65. Geburtstag. München, 1988. 237-253.

DE Bray 1980a = DE Bray R. G. A. Guide to the South Slavonic Languages. (Guide to the Slavonic Languages.) Part 1. Columbus: Slavica, 1980.

DE Bray $1980 \mathrm{~b}=$ DE BRAY R. G. A. Guide to the West Slavonic Languages. (Guide to the Slavonic Languages.) Part 2. Columbus: Slavica, 1980.

DE BRAY 1980c = DE BRAY R. G. A. Guide to the East Slavonic Languages. (Guide to the Slavonic Languages.) Part 3. Columbus: Slavica, 1980.

Haspelmath 2001 = Haspelmath M. The European linguistic area: Standard Average European. In: HASPELMATH M. et al. (ed.) Language Typology and Language Universals. Vol. 2. Berlin-New York: de Gruyter, 2001. 1492-1510.

JAKOBSON $1955=$ JAKOBSON R. Slavic Languages. A Condensed Survey. New York: Columbia University, 1955.

JANDA $1996=$ JANDA L. A. Back from the Brink. A Study of How Relic Forms in Languages Serve as Source Material for Analogical Extension. München-Newcastle: Lincom Europa, 1996.

Johnson $1972=$ Johnson D. J. L. The Genesis of the Serbo-Croatian Genitive Plural in $-\bar{a}$. The Slavonic and East European Review 50 (1972): 333-358.

Mayo 1993 = Mayo P. Belorussian. In: Comrie B., Corbett G. G. (ed.) The Slavonic Languages. London-New York: Routledge, 1993. 887-946.

Polański 1993 = PolańsKi K. Polabian. In: Comrie B., Corbett G. G. (ed.) The Slavonic Languages. London-New York: Routledge, 1993. 795-824.

Shevelov $1964=$ Shevelov G. Y. A Prehistory of Slavic. Heidelberg: Carl Winter Universitätsverlag, 1964.

Short 1993 = Short D. Czech. In: Comrie B., Corbett G. G. (ed.) The Slavonic Languages. London-New York: Routledge, 1993. 455-532. 
STANKIEWICZ $1958=$ STANKIEWICZ E. Towards a phonemic typology of the Slavic languages. In: American Contributions to the Fourth International Congress of Slavicists. Moscow, September 1958. The Hague: Mouton \& Co., 1958. 301-319.

Tommola 2011 = Tommola H. On Slavic and Finno-Ugric vs. Standard Average European. In: Kosta P., SchÜRCKS L. (ed.) Formalization of Grammar in Slavic Languages. Frankfurt am Main: Peter Lang, 2011. 365-390.

H. То́тн $2004=$ H. То́тн Imre: Bevezetés a szláv nyelvtudományba. Szeged-Szombathely, 2004.

\section{GÁBOR L. BALÁZS \\ Institute of Slavic Philology, Faculty of Arts, University of Szeged}

\section{An Overview of Alternative Typologies of Slavic Languages}

The typology of Slavic languages has been frequently dealt with in different publications since the late 19th century. In this paper, the author reviews some of the most significant attempts aimed at the phonological, morphological, and syntactic levels of this typological research. It appears that the phonological classification first elaborated by Baudouin de Courtenay has remained reliable to this day. In morphology, however, the only method for categorization seems to be the identification of certain grammatical markers. Syntactic typology is still a young field of linguistics; nevertheless, there exist promising ventures in it, too. It is remarkable that the typological findings for the modern Slavic languages to a large extent coincide with the results of areal studies.

Based on the information presented in the paper, the following implications can be made with reference to the typology of the specific linguistic levels in the Slavic languages.

The most uniform level is that of phonological typology because in all the models presented here, a key role is played by two prosodic features: the opposition of long and short vowels, on the one hand, and the character of word stress, on the other. Thus, the phonological typology first elaborated by Baudouin de Courtenay has proved to be reliable up to the present. At least no competing theories in this field can be seen for the time being.

As to morphological typology, it is not possible to identify features or criteria similar to the phonological models which could be applied for the differentiation of whatever morphological types. The Slavic languages, even Bulgarian and Macedonian, which have no nominal declension, have remained fusional (inflectional) languages, within which it is not easy to delineate further subtypes. So far, the only way of morphological categorization seems to be the identification and comparison of individual grammatical features of the different Slavic languages, as it is illustrated tentatively in Section 2.

The syntactic typology of the Slavic languages is still a very young field of typological research. Therefore, it is impossible to arrive at any general conclusions on this matter (besides the ones mentioned in Section 3). The model offered by Haspelmath for the European languages looks quite promising but it is necessary to work out further details and specific methods so that it could be successfully applied specifically for the Slavic languages.

One cannot fail to notice that the typological regularities specified by way of the morphological and syntactic observations in Sections 2 and 3, to a marked extent coincide with the facts of the areal (geographical) classification of the Slavic languages, as it was sharply noticed by Bogoroditsky, Janda, Tommola, and other researchers.

Keywords: Slavic languages, typology, phonology, morphology, syntax, Baudouin de Courtenay, Haspelmath, fusional languages 
Open Access. This is an open-access article distributed under the terms of the Creative Commons Attribution 4.0 International License (https://creativecommons.org/licenses/ by/4.0), which permits unrestricted use, distribution, and reproduction in any medium, provided the original author and source are credited, a link to the CC License is provided, and changes - if any - are indicated. (SID_1) 